\title{
THREE METHODS TO EVALUATE THE USE OF EVAPORATIVE COOLING FOR HUMAN THERMAL COMFORT
}

\author{
J. R. Camargo ${ }^{\mathrm{a}}$, \\ C. D. Ebinuma ${ }^{b}$, \\ and S. Cardoso ${ }^{a}$ \\ ${ }^{a}$ Universidade de Taubaté \\ Departamento de Engenharia Mecânica \\ Rua Daniel Danelli, s/n \\ CEP. 12060-440, Taubaté, SP, Brasil

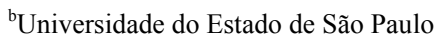 \\ Departamento de Energia \\ Rua Ariberto Pereira da Cunha, 333 \\ CEP. 12500-000, Guaratinguetá, SP, Brasil \\ rui@mec.unitau.br
}

\begin{abstract}
This paper presents three methods that can be used as reference for efficient use of evaporative cooling systems, applying it, latter, to several Brazilian cities, characterized by different climates. Initially it presents the basic principles of direct and indirect evaporative cooling and defines the effectiveness of the systems. Afterwards, it presents three methods that allows to determinate where the systems are more efficient. It concludes that evaporative cooling systems have a very large potential to propitiate thermal comfort and can still be used as an alternative to conventional systems in regions where the design wet bulb temperature is under $24^{\circ} \mathrm{C}$.
\end{abstract}

Keywords: Evaporative Cooling, Thermal Comfort, Air Conditioning

\section{INTRODUCTION}

Air conditioning is responsible for the increase of the efficiency of the man in his job as well as for his comfort, mainly in warm periods along the year. Currently, the most used system is the mechanical vapor compression system. However, in many cases, evaporative cooling can be an economic alternative and may replace the conventional system in many circumstances or may be used as a pre-cooler for conventional systems.

Evaporative cooling operates utilizing natural phenomena through induced process where water and air are the working fluids. It consists in the utilization of water evaporation through the passage of an airflow, decreasing the air temperature.

The main characteristic of this process is the fact that it is more efficient in higher temperatures, in other words, when more cooling is needed. Moreover, in dry regions, the increase of humidity is salutary and, in some others, with increase of humidity of the air supplied, it avoids air dehumidification, a typical discomfort present in conventional systems. Evaporative cooling has the additional attractiveness of low energy consumption, easy maintenance, installation and operation. Because it does not use CFC or HFC gases it does not pollute the environment. Because it is a system that operates with total airflow renewal, it eliminates the recirculation flow and proliferation of fungi and bacteria, a constant problem in conventional air conditioning systems.

Due to its characteristics the evaporative cooling is more efficient in places where the climate is hot and dry but it can also be used under other climatic conditions. This paper proposes to determinate where, when, how and what is the operational efficiency of these systems and, for this, three methods are presented in order to establish references, applied to several Brazilian cities, characterized by different climates.

The first method is based on Watt (1963) and uses the dry and wet bulb temperature to determine the "feasibility index" through which is possible to classify the cities, related to comfort gain by evaporative cooling. It's a fast method to evaluate the potential of evaporative cooling. The second method defines, in the psychometric chart, a zone from which it is possible to obtain, by evaporative cooling, the thermal comfort zone presented by Crow (1972) and recommended by the ASHRAE, using, for this, representative vectors of the cooling process. Finally the third method is based on Watt (1963) and Watt \& Brown (1997) adapting a thermometric chart that shows the interrelationship between dry and wet bulb temperatures and air speed in the creation of the effective temperatures. It allows to determinate the external climatic conditions necessary to obtain comfort and relief cooling.

\section{RECENT DEVELOPMENTS}

Several authors dedicated their researches to the development of direct, indirect and regenerative evaporative cooling systems. Watt (1963) developed the first serious analyses of direct and indirect evaporative systems, Pescod (1968) developed plastic plate heat exchanger; Eskra (1980) presented a two stage system associating a direct and an indirect evaporative cooling in order to increase the system's efficiency, Supple and Broughton (1985) described some systems where indirect evaporative cooling is 
used, Maclaine-Cross and Banks (1983) developed equations to model evaporative regenerative heat exchanger, Nation (1984) discussed the operation of several types of evaporative cooling systems, dealing mainly with multistage systems, Anderson (1986) analyzed the economy obtained from a three stage system (direct / indirect and a third one by mechanical cooling with direct expansion or cold water), McClellan (1988) presented performance of several evaporative cooling (single direct stage, single indirect stage and two stage direct / indirect) working in five cities in USA with different climates condition, Liesen and Pedersen (1991) presented five configurations of evaporative cooling for energy analysis through BLAST software (Building Loads Analysis and System Thermodynamics), Belding and Delmas (1997) developed a compact modulus of indirect evaporative cooling to be used in individual air conditioning systems, Schibuola (1997) used the return air for energy recovery, Halasz (1998) presented a general dimensionless mathematical model to describe all evaporative cooling devices used today (cooling water towers, evaporative condensers of fluid, air washes, dehumidification coils and others). Recently Cardoso, Camargo and Travelho (1999) worked on a research where a thermal balance study for direct and indirect cooling systems is developed.

\section{EVAPORATIVE COOLING SYSTEMS}

Evaporative cooling process is commonly used in cooling water towers, air washes, evaporative condensers, fluid cooling and also to soothe the temperature in places where several heat sources are present. However it is seldom utilized for human thermal comfort.

Evaporative cooling equipment can be direct evaporative cooler (DEC) or indirect evaporative cooler (IEC).

Direct evaporative cooling equipment decrease air temperature by direct contact with a liquid surface or a wet solid surface or else with the use of spray systems. Figure 1 shows a schematic direct evaporative cooling system.

In a DEC, water is vaporized inside the air streams and heat and mass transferred between air and water decreases the air dry bulb temperature (DBT) and increases its humidity, keeping the enthalpy constant (adiabatic cooling); the minimum temperature that can be reached is the wet bulb temperature (WBT) of the incoming air.

Another system uses indirect cooling equipment, where air, relatively dry, is separated from the wet airside, where liquid have been evaporated. In the indirect evaporative cooling system (IEC), the process air (primary air) transfers heat to a secondary airflow or to a liquid that has been cooled by evaporation. Both dry side and air enthalpy on this side are decreased, in contrast to the temperature adiabatic decrease of a direct evaporative cooling.

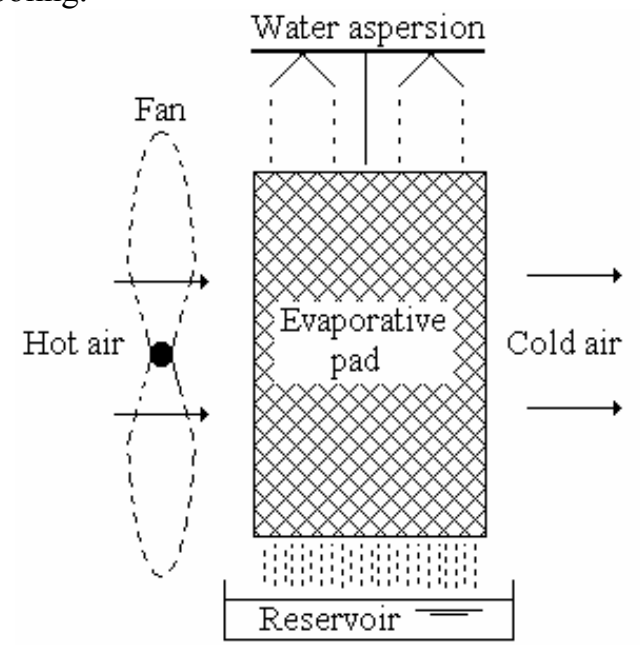

Figure 1. Direct evaporative cooling (DEC)

Figure 2 shows two kinds of indirect evaporative cooling system: Type plate (Fig. 2a) and type tube (Fig. 2b).

The effectiveness of an evaporative cooling is defined as the rate between the real decrease of dry bulb temperature and the maximum theoretical decrease that dry bulb temperature could have if the cooling were $100 \%$ efficient and the outlet air were saturated. In this case the outlet dry bulb temperature would be equal to the inlet wet bulb temperature (TRANE, 1978).

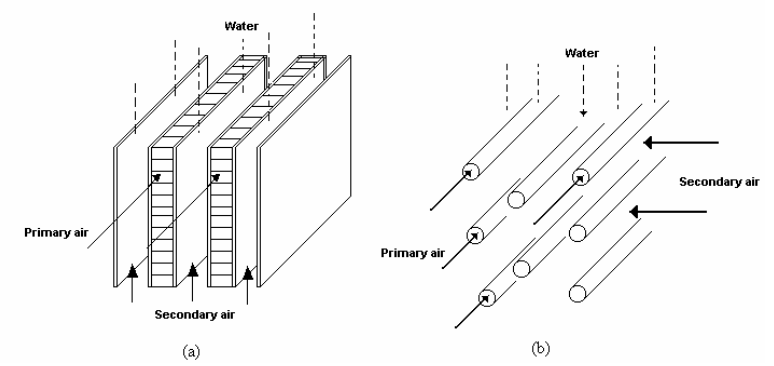

Figure 2. Indirect evaporative cooling: (a) type plate, (b) type tube.

Figure 3 illustrates what happens with dry bulb temperature (DBT), wet bulb temperature (WBT) and dew point temperature (DPT) when the air runs goes through an evaporative cooler.

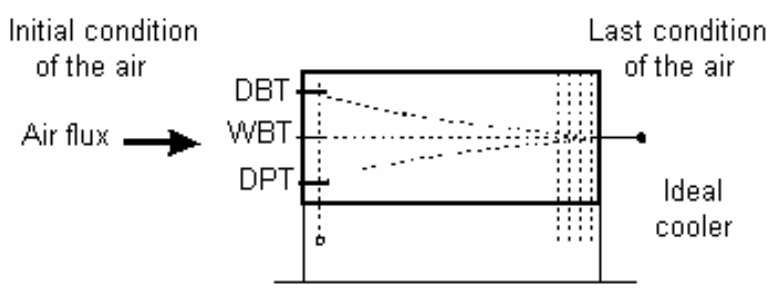

Figura 3. Spray evaporative cooling with constant water flow. 
For an ideal evaporative cooler, it means, $100 \%$ efficient, the dry bulb temperature and dew point should be equal to the wet bulb temperature.

The psychometric chart in Fig. 4 illustrates what happens when the air runs through an evaporative unity. Assuming the condition that the inlet dry bulb temperature is $35^{\circ} \mathrm{C}$ and the wet bulb temperature is $25^{\circ} \mathrm{C}$ (point 1), the initial difference is $10^{\circ} \mathrm{C}$. The process 1-2 represents an indirect evaporative unity and the process 1-3 represents a direct evaporative unity. If the efficiency of the direct unity is $90 \%$ (Munters, 1999), the depression will be $9^{\circ} \mathrm{C}$ and the dry bulb temperature of the air leaving this unity will be $35-0.9$ x $10=26^{\circ} \mathrm{C}$ (point 3). Taking a $70 \%$ efficiency for the indirect unity (Munters, 1999), the dry bulb temperature of the air leaving this unity will be $28^{\circ} \mathrm{C}$ (point 2).

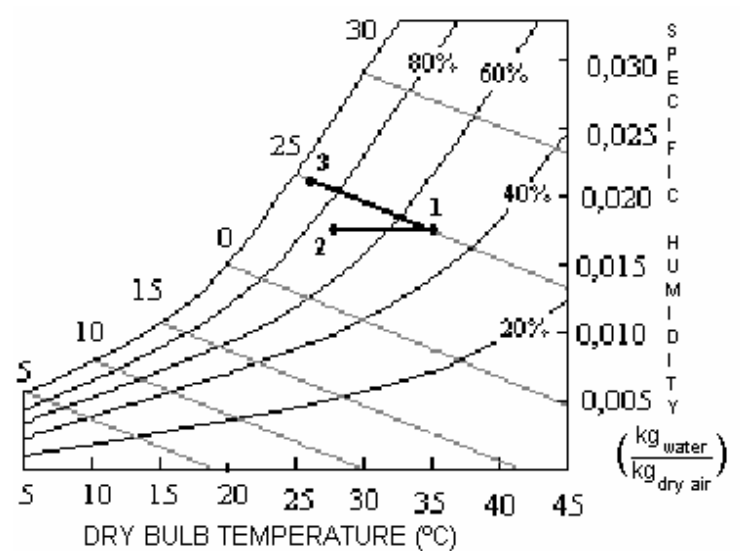

Figure 4. Psychometric chart showing the condition: (1) outside air, (2) air leaving the indirect unity and (3) air leaving the direct unity.

In an evaporative cooler, water supplying the unity is re-circulated and only a part of this is evaporated. The re-circulated water reaches a balance temperature close to the inlet air wet bulb temperature.

\section{METHODS TO EVALUATE EVAPORATIVE COOLING SYSTEMS}

This section presents three methods that may be used to verify the viability of using evaporative cooling equipment of air conditioning for human thermal comfort and their application to several cities.

\section{METHOD 1: FEASIBILITY INDEX}

A fast method to evaluate approximately the potential of the evaporative cooling is based on the Feasibility Index (FI), defined by:

$$
\mathrm{FI}=\mathrm{WBT}-\Delta \mathrm{T}
$$

Where $\Delta \mathrm{T}=(\mathrm{DBT}-\mathrm{WBT})$ is the wet bulb depression. DBT and WBT are, respectively the dry bulb temperature and the wet bulb temperature of the outside air. This index decreases as the difference between dry bulb and wet bulb temperature increases, i.e. as air relative humidity decreases. It shows that, the smaller FI is, more efficient the evaporative cooling will be. Thus, this number indicates the evaporative cooling potential to give thermal comfort.

Watt (1963, pp. 54) recommend that indices that are under or equal to 10 indicate a comfort cooling, indices between 11 and 16 indicate lenitive cooling (relief) and indices above 16 classify the place as not recommended for use evaporative cooling systems.

From these limits it is possible to conclude that, to reach a comfort recommended performance index, a wet bulb depression from, at least, $12^{\circ} \mathrm{C}$, is needed. It corresponds, e.g. to a DBT of $34^{\circ} \mathrm{C}$ with WBT of $22^{\circ} \mathrm{C}$, characterizing a region with relative humidity of approximately $35 \%$.

\section{METHOD 2: COOLING PROCESS VECTORS}

Another method to determine vaporative cooling potential is through a psychometric chart giving comfort areas and vectors representing the cooling process. Local climatic condition must be plotted in this chart giving the vector application point. If, through evaporative cooling vector representation is possible to reach the comfort zone, then evaporative systems are possible to be used in that region.

This method determines, in the psychometric chart, a zone, from where it is possible to reach the comfort zone by means of direct or indirect cooling. Figure 6 shows the result.

Figure 5 shows vectors of three different cooling processes:

$\mathrm{AB}$ - direct evaporative cooling

$\mathrm{AD}$ - indirect first stage $(\mathrm{AC})$ and direct second stage (CD)

$\mathrm{EF}$ - conventional air conditioning

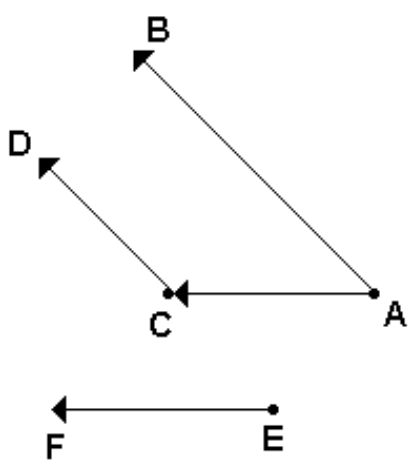

Figure 5. Cooling process vectors. 
To determine this zone limits, values of the specific humidity were fixed and its corresponding dry bulb temperature $\left(\mathrm{DBT}_{\mathrm{C}}\right)$ on the limit line of the comfort zone were obtained, that is,

$$
\mathrm{DBT}_{\mathrm{C}}=\mathrm{DBT}_{\mathrm{L}}-\varepsilon_{\mathrm{i}}\left(\mathrm{DBT}_{\mathrm{L}}-\mathrm{WBT}\right)
$$

where $\mathrm{DBT}_{\mathrm{C}}$ is the dry bulb temperature in the limit line on the right, $\mathrm{DBT}_{\mathrm{L}}$ is the dry bulb temperature in the limit line of the ASHRAE comfort zone and $\varepsilon_{\mathrm{I}}$ is the indirect first stage efficiency. With the help of a software developed by the authors, the values of its corresponding wet bulb temperature $\mathrm{WBT}_{\mathrm{W}}$ and, finally, the $\mathrm{DBT}_{\mathrm{L}}$ temperature of the above equation where obtained.

If the point is under the representative line of an IEC with $\varepsilon_{\mathrm{i}}=60 \%$ or $70 \%$ it is possible to use this system for comfort cooling.

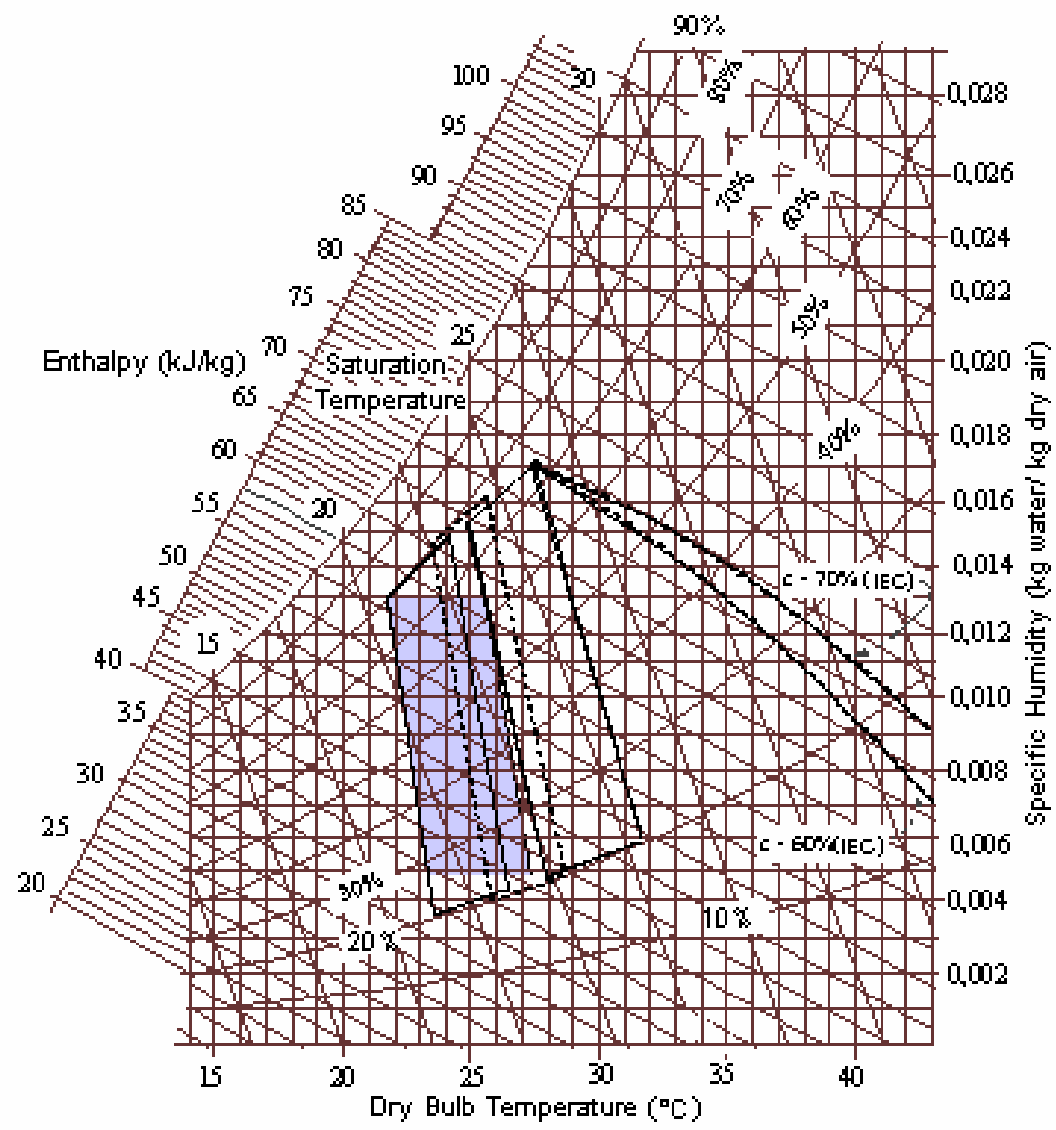

Figure 6. Delimitation of the area where it is possible to reach the evaporative cooling comfort area.

\section{METHOD 3: NOMOGRAPH TEMPLATE}

This method is an adaptation of what was proposed by Watt (1963, pp. 48) and by Watt and Brown (1997, pp. 38).

If both final indoor or process condition are known for each region, the effective temperature chart allows the determination of the maximum permissible local outdoor wet bulb temperature and the minimum average outdoor wet bulb depression required for such performance. The first one becomes the maximum permissible design wet bulb temperature for the location and the latter is converted into the required minimum design wet bulb depression.

Figure 7 is an adapted thermometric chart that shows the interaction, during summer, of the dry bulb temperature, wet bulb temperature and air speed in the representation of the effective temperature. ASHRAE comfort zone for $41^{\circ}$ North Latitude (the first comfort chart was made in Pittsburgh, in this latitude) has been superimposed upon it, its upper limit on $26.1^{\circ} \mathrm{C}$ temperature effective.

To determine the outdoor climatic condition necessary to achieve the comfort cooling, as defined above, a calculator template, showed in its inferior side, is used and it is useful to fix the 
comfort cooling limits (superior template) and to the relief (inferior template).

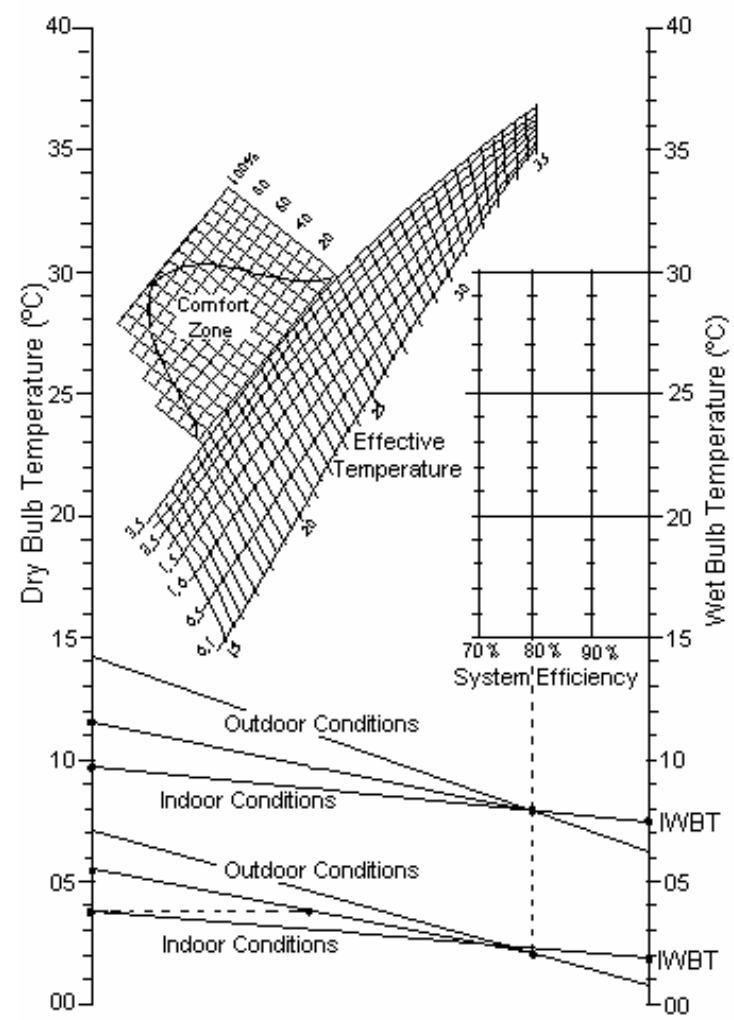

Figure 7. Nomograph and template (Camargo, 2000).

In order to use the template, first it is necessary to copy it into a transparent paper. Then put it over the chart with the "indoor conditions" line crossing the intersection of the maximum permissible air speed with the regional comfort zone maximum permissible effective temperature. The template lower right intersection indicates maximum outdoor wet bulb temperature able to give comfort, under the given conditions. The template maximum difference between dry bulb temperature and wet bulb temperature indicates the minimum average outdoor wet bulb depression required.

\section{RESULTS AND DISCUSSION}

Using the method called "Feasibility Index (FI)", whose values give the possibility of obtaining cooling for comfort or relief, it is possible to check that performance index values under or equal to 10 are obtained, for example, to Cordoba and Tucaman, in Argentina, and Santiago, in Chile. In Brazil it is possible to find indices between 11 and 16 for Petrolina (PE), Uberlândia (MG), Campinas (SP), Pirassununga (SP), Brasilia (DF), Campo Grande (MT), Londrina (PR), Caxias do Sul (RS) and Santa Maria (RS), among others (see Table 1).
Table 1. Feasibility Index for several cities.

\begin{tabular}{|c|c|c|c|}
\hline CITIES & DBT & WBT & FI \\
\hline \multicolumn{4}{|l|}{ 1. Northern Region } \\
\hline Macapá (AP) & 34 & 28,5 & 23 \\
\hline Manaus (AM) & 35 & 29 & 23 \\
\hline Santarém(PA) & 35 & 28,5 & 22 \\
\hline Belém(PA) & 33 & 27 & 21 \\
\hline \multicolumn{4}{|l|}{ 2.Northwestern Region } \\
\hline João Pessoa(PB) & 32 & 26 & 20 \\
\hline São Luis(MA) & 33 & 28 & 28 \\
\hline Parnaiba (PI) & 34 & 28 & 22 \\
\hline Teresina(PI) & 38 & 28 & 18 \\
\hline Fortaleza(CE) & 32 & 26 & 20 \\
\hline $\operatorname{Natal(RN)}$ & 32 & 27 & 22 \\
\hline Recife(PE) & 32 & 26 & 20 \\
\hline Petrolina(PE) & 36 & 25,5 & 15 \\
\hline Maceió(AL) & 33 & 27 & 21 \\
\hline Salvador(BA) & 32 & 26 & 20 \\
\hline Aracaju(SE) & 32 & 26 & 20 \\
\hline \multicolumn{4}{|l|}{ 3. Southwestern Region } \\
\hline Vitória(ES) & 33 & 28 & 23 \\
\hline Belo Horizonte(MG) & 32 & 24 & 16 \\
\hline Uberlândia(MG) & 33 & 23,5 & 14 \\
\hline Rio de Janeiro(RJ) & 35 & 26,5 & 18 \\
\hline São Paulo(SP) & 31 & 24 & 17 \\
\hline Santos(SP) & 33 & 27 & 21 \\
\hline Campinas(SP) & 33 & 24 & 15 \\
\hline Pirassununga(SP) & 33 & 24 & 15 \\
\hline \multicolumn{4}{|l|}{ 4. Centerwestern Region } \\
\hline Brasilia(DF) & 32 & 23,5 & 15 \\
\hline Goiânia(GO) & 33 & 26 & 19 \\
\hline Cuiabá(MT) & 36 & 27 & 18 \\
\hline Campo Grande(MT) & 34 & 25 & 16 \\
\hline Ponta-Porã(MT) & 32 & 26 & 20 \\
\hline \multicolumn{4}{|l|}{ 5. Southern Region } \\
\hline Curitiba(PR) & 30 & 23,5 & 17 \\
\hline Londrina (PR) & 31 & 23,5 & 16 \\
\hline Foz de Iguaçu(PR) & 34 & 27 & 20 \\
\hline Florianópolis(SC) & 32 & 26 & 20 \\
\hline Joinville(SC) & 32 & 26 & 20 \\
\hline Blumenau(SC) & 32 & 26 & 20 \\
\hline Porto Alegre(RS) & 34 & 26 & 18 \\
\hline Santa Maria(RS) & 35 & 25,5 & 16 \\
\hline Rio Grande(RS) & 30 & 24,5 & 19 \\
\hline Pelotas(RS) & 32 & 25,5 & 19 \\
\hline Caxias do Sul(RS) & 29 & 22 & 15 \\
\hline Uruguaiana(RS) & 34 & 25,5 & 17 \\
\hline
\end{tabular}


Through "vectors cooling process" method it is possible to verify that a basic requirement to fit onto a region where it is possible to reach the comfort zone is the wet bulb temperature being below $24^{\circ} \mathrm{C}$. In regions where climatic conditions do not allow reaching the comfort zone only through evaporative cooling, it is possible to use a pre-dehumidification process of the air by adsorption, direct / indirect associated systems or to use the mechanical cooling as a support system. Some Brazilian cities, whose the climatic condition allow to reach the comfort zone by evaporative cooling are: Belo Horizonte, Brasilia, Campinas, Caxias do Sul, Curitiba, Londrina, São Paulo and Uberlândia, among others (see Table 2).

Table 2. Temperatures outlet stages.

\begin{tabular}{|l|c|c|c|}
\hline \multicolumn{1}{|c|}{ Cities } & $\begin{array}{c}\text { DBT/WBT } \\
\text { design }(1 \%)\end{array}$ & $\begin{array}{c}\text { DTB outlet } \\
\text { indirect first } \\
\text { stage }\left({ }^{\circ} \mathrm{C}\right)\end{array}$ & $\begin{array}{c}\text { DBT outlet } \\
\text { direct second } \\
\text { stage }\left({ }^{\circ} \mathrm{C}\right)\end{array}$ \\
\hline Belém & $32,3 / 27$ & 29,1 & 26,5 \\
\hline Belo Horizonte & $30 / 24,4$ & 26,6 & 23,8 \\
\hline Brasilia & $30 / 22$ & 25,2 & 22,8 \\
\hline Curitiba & $30 / 23$ & 25,8 & 22,2 \\
\hline Florianópolis & $32 / 27,1$ & 29,1 & 26,7 \\
\hline Fortaleza & $31,4 / 26$ & 28,2 & 25,5 \\
\hline Maceió & $32 / 25,7$ & 28 & 24,7 \\
\hline Natal & $31,5 / 25,7$ & 28 & 25,1 \\
\hline Porto Alegre & $35 / 26,3$ & 29,8 & 25,5 \\
\hline Recife & $31,6 / 25,8$ & 28,1 & 25,2 \\
\hline Rio de Janeiro & $35,3 / 27,3$ & 30,5 & 26,6 \\
\hline Salvador & $31,2 / 26,1$ & 28,1 & 25,6 \\
\hline São Luis & $32,5 / 26,5$ & 28,9 & 25,9 \\
\hline São Paulo & $30,6 / 23$ & 26 & 22,1 \\
\hline Vitória & $33,5 / 27,4$ & 29,8 & 26,8 \\
\hline
\end{tabular}

The method called "nomograph and template" allows to determinate the maximum design WBT and, through it, it is possible to obtain the results described below.

The comfort zone increases the effective temperature curve by $5^{\circ} \mathrm{C}$ for each $5^{\circ}$ reduction in latitude. Evaporative cooling placed in northern Argentina, Uruguay and Rio Grande do Sul must obtain maximum $26.8^{\circ} \mathrm{C}$ ET (effective temperature), requiring $24.4^{\circ} \mathrm{C}$ design WBT or lesser, for air speed of $0.1 \mathrm{~m} / \mathrm{s}$. At the same way, with the same air speed, regions in northern Rio Grande do Sul, Santa Catarina and in southern Paraná must have $27.3^{\circ} \mathrm{C} \mathrm{ET}$ or less, where $24.9^{\circ} \mathrm{C}$ is the maximum permissible design WBT. In northern Paraná, São Paulo, Rio de Janeiro, Mato Grosso do Sul and in southern Minas Gerais the comfort cooling needs to obtain $27.8^{\circ} \mathrm{C}$ ET or less, requiring the maximum design $\mathrm{WBT}$ of $25.5^{\circ} \mathrm{C}$. Northern Minas Gerais and southern Mato Grosso and Goiás require maximum design WBT of $26^{\circ} \mathrm{C}$. Bahia, southern Tocantins, northern Mato Grosso, Rondonia and Acre require maximum design WBT of $26.6^{\circ} \mathrm{C}$. Southern Maranhão, northern Tocantins, southern Pará and southern Amazonas request maximum design WBT of $27.3^{\circ} \mathrm{C}$. Finally, the northern Maranhão, northern Pará, northern Ceará, northern Amazonas, Amapá and Roraima require maximum design WBT of $27.9^{\circ} \mathrm{C}$. The values presented above are related to the maximum required design $\mathrm{WBT}$, that is, the temperature that takes to the upper limit of the comfort zone presented in the nomograph of Fig.7. For WBT values providing comfort to $100 \%$ of the occupants, the temperatures presented above must be reduced in approximately $4.5^{\circ} \mathrm{C}$.

\section{CONCLUSIONS}

This paper presents a methodology and a systematic study related to evaporative cooling systems applied to tropical and equatorial regions and the methods presented here are useful to evaluate the technical viability of evaporative cooling systems for human thermal comfort. It allows to the correct determination of where and how evaporative cooling systems can be efficiently used.

Evaporative cooling systems, although not widely used in Brazil, have a very large potential to produce thermal comfort and can be an alternative to the conventional systems in regions where the wet bulb temperature is relatively low. Moreover, it may also be used with conventional systems where only the evaporative system cannot supply all of the needs for comfort. Some possible alternatives are the multistage systems and the adsorption prehumidifying systems.

Regions with design wet bulb temperature lower than $24^{\circ} \mathrm{C}$ are natural regions where evaporative cooling air conditioning may be used.

The most important data for an engineer or designer, however, when considering evaporative system applications, is updated climatic registers for the specific region in order to find out what can be done with regard to thermal comfort.

The methods presented in this paper, although illustrated for evaporative cooling, may also be used for other air conditioning systems.

\section{REFERENCES}

Anderson, W. M., 1986, “Three-stage evaporative air conditioning versus conventional mechanical refrigeration", ASHRAE Transactions, Vol. 92, pp. 358-370.

Belding, W. A., Delmas, M.P.F., 1997, "Novel desiccant cooling system using indirect evaporative cooler", ASHRAE Transactions, Vol. 103, Part 1, pp. 841-847.

Camargo, J. R., 2000, “Análise de métodos para avaliar a viabilidade técnica de sistemas de resfriamento evaporativo aplicados ao condicionamento de ar para conforto", Master Thesis, Mechanical Engineering Department, University of Taubaté, Taubaté , SP, Brazil, 160p. 
Cardoso, S., Camargo, J. R., Travelho, J. S., 1999, "Introdução à utilização do resfriamento evaporativo para condicionamento de ar automotivo", XV Brazilian Congress of Mechanical Engineering, COBEM99, Águas de Lindóia, SP.

Crow, L. W., 1972, "Weather data related to evaporative cooling", Research Report n. ${ }^{\circ} 2223$. ASHRAE Transactions 78 (1): pp. 153-164.

Eskra, N., 1980, "Indirect/direct evaporative cooling systems", ASHRAE Journal, may, 1980, pp. 21-25;

Halasz, B., 1998, "A general mathematical model of evaporative cooling devices", Rev. Gén. Therm., FR, Vol. 37, pp. 245-255, Elsevier, Paris.

Liesen, R. J., Pedersen, C. O., 1991, "Development and demonstration of an evaporative cooler simulation model for blast energy analysis computer program", ASHRAE Transactions, Vol. 97, Part 2, pp. 866-873.

Maclaine-cross, I. L., Banks, P. J., 1981, “A general theory of wet surface heat exchangers and its application to regenerative evaporative cooling", Journal of Heat Transfer, Vol.103, No. 3, pp. 579585.

McClellan, C. H., 1988, "Estimated temperature performance for evaporative cooling systems in five locations in the United States", ASHRAE Transactions, 94 (2), pp. 1071-1090.

Munters, 1999, "Sistema de ventilação com resfriamento do ar através do processo natural de evaporação da água", lecture notes, Curitiba.

Nation, J. A., 1984, "Evaporative Cooling in Nontraditional Climates", ASHRAE Transactions, Vol. 90, Part 1, pp. 154-165.

Pescod, D., 1968, "Unit air cooler using plastic heat exchanger with evaporatively cooled plates", Australian Refrigeration, Air Conditioning and Heating, Vol. 22, No. 9, pp. 22-26.

Schibuola, L., 1997, "High-efficiency recovery for air-conditioning applications in a mild climate: a case study", Applied Thermal Engineering, Vol. 17, No. 5, pp. 447-454.

Supple, R. G., Broughton, D. R., 1985, "Indirect evaporative cooling - Mechanical cooling design", ASHRAE Transactions, Vol. 91, Part 1B, pp. 319-328.

TRANE, 1978, “Air conditioning handbook". The Trane Company, La Crosse, Wisconsin.

Watt, J.R., 1963, "Evaporative air conditioning", The Industrial Press, New York.

Watt, J. R., Brown , W. K., 1997, "Evaporative air conditioning handbook", 3rd Edition, The Fairmont Press, Inc., Lilburn, GA.

\section{ACKNOWLEDGEMENTS}

The authors acknowledge the National Council for Scientific and Technological Development $(\mathrm{CNPq})$ for financial support.

\section{COPYRIGHT NOTICE}

The authors are the only responsible for the printed material included in this paper.

\footnotetext{
Received: February 05, 2006

Revised: March 05, 2006

Accepted: April 05, 2006
} 